\title{
A NATION OF ANIMAL LOVERS? THE CASE FOR A GENERAL ANIMAL KILLING OFFENCE IN UK LAW
}

\author{
Joe Wills*
}

This article argues that criminal liability for offences against animals under UK law should be extended to include offences of killing, even if the death caused is painless and does not interfere with property rights or biodiversity. I defend this position by appealing to two norms that have significant purchase in the UK legal context: (1) the value of protecting animal welfare and (2) the harm principle as a basis for criminalisation. It will be argued that killing itself is a welfare issue, as it deprives sentient beings of future good experiences and can reduce their lifetime wellbeing to levels lower than it otherwise would have been. Joel Feinberg's normative work on criminalisation is drawn upon to argue that the harm principle, properly conceived, restricts liberty to protect both humans and other sentient animals from harm, including the harm of death in some instances. Potential objections to this claim are considered and rejected.

\section{INTRODUCTION}

The frequent claim that Britain is a 'nation of animal lovers' can be hard to reconcile with the reality of how we often treat even the most revered of our fellow creatures. A survey published by the British Veterinary Association in 2016 showed that 98 per cent of vets have been asked to kill healthy pets, with 53 per cent saying that this is not a rare occurrence. ${ }^{1}$

This widespread killing of healthy animals occurs in part because UK law has a onesided fixation with the quality, but not the preservation, of animal life. ${ }^{2}$ Despite the voluminous body of legislation that has been enacted in Britain over the last 200 years to regulate the treatment of animals while they are alive, the law in general does not impose any restrictions upon killing them. ${ }^{3}$

\footnotetext{
* LLB, LLM, PhD. Lecturer in Law, University of Leicester. I would like to thank Robert Garner, Steve Cooke, Alistair Cochrane, Francois du Bois and the anonymous referee for their helpful comments on earlier drafts of this article as well as the participants and organisers of the Conference on Animal Law, Ethics and Legal Education at Liverpool John Moores University in 2017. Any errors are my own.

${ }^{1}$ British Veterinary Association, “"Hidden, tragic cost" of Poorly Socialised Pets: Survey Reveals $98 \%$ of Vets Asked to Euthanise Healthy Pets' (British Veterinary Association, 6 September 2016) <https://www.bva.co.uk/News-campaigns-andpolicy/Newsroom/News-releases/Survey-reveals-98--of-vets-asked-to-euthanise-healthy-pets/> accessed 14 August 2018. ${ }^{2}$ In this article I use 'animal' as a shorthand for 'sentient non-human animal', by which I mean members of species other than homo sapiens who have subjective awareness and the capacity to experience pleasure and suffering.

${ }^{3}$ Mike Radford, Animal Welfare Law in Britain: Regulation and Responsibility (OUP 2001) 336-339.
} 
This article challenges this status quo and suggests that in some instances it ought to be a criminal offence to kill an animal, even if the death is painless and does not interfere with property rights or biodiversity. From the outset, two points should be made about this position. First, this article does not advance any particular, detailed proposal for the framing of a future animal killing offence, although it will make some rough suggestions in the conclusion. Nor does it attempt to mount an empirical case as to why such a new offence would be desirable. Rather, the focus of the article is primarily normative and conceptual. It makes a largely a priori case in favour of an animal killing offence based on first principles. As such it should be understood as the beginning of a debate concerning what the law's position on the killing of animals ought to be.

Second, the conclusion of the article is arrived at through immanent critique, i.e. criticism of the law's current state using its own internal standpoint. In particular, I argue that the absence of any general animal killing offences in UK law stands in tension with two norms that already have significant purchase in its legal context: (1) the value of protecting animal welfare and (2) the harm principle as a basis for criminalisation. In drawing on these principles I will rely on their most developed articulations which, in relation to the harm principle, I take to be found in the four-volume work on the basis for criminalisation written by Joel Feinberg. ${ }^{4}$

The article is divided into four main parts. Part 1 will set out what the current legal position on the killing of animals is in the UK. Part 2 contrasts this legal position to other jurisdictions that have adopted broader-based prohibitions on the killing of animals. Part 3 argues that animal welfare is treated as having independent value by contemporary animal protection legislation. It then argues that killing animals is potentially a welfare issue insofar as it deprives them of future pleasurable experiences and reduces their lifetime wellbeing to levels lower they would otherwise have been had they continued to live. Part 4 lays out an alternative, but complementary, argument in favour of introducing an animal killing offence. This argument is derived from four premises: (1) the harm principle, correctly formulated, provides good reason to criminalise conduct; (2) animals are within the class of beings whose protection provides a basis for liberty restriction under the harm principle; (3) killing harms an animal when it deprives them of a life worth living; (4) sometimes it is unjustifiable to harm an animal by killing them.

\footnotetext{
${ }^{4}$ See section 4 .
} 


\section{THE LAW ON KILLING ANIMAL IN BRITAIN}

The main way in which $\mathrm{UK} \mathrm{law}^{5}$ regulates the killing of animals is through placing limitations on the means by which they are killed. Under the Animal Welfare Act 2006 (AWA), domesticated and captive animals are protected from unnecessary suffering, including at the time of killing. ${ }^{6}$ In the context of farmed animals, specific provisions are set out in the Welfare of Animals at the Time of Killing Regulations, which includes, amongst other things, a requirement that animals ought standardly to be stunned prior to slaughter. ${ }^{7}$ Likewise, the Wildlife and Countryside Act 1981 makes it an offence to use any self-locking snare, bow, crossbow, explosive or decoy to kill wild animals. ${ }^{8}$ What is proscribed by these laws is not killing per se, but rather particular methods of killing that cause unnecessary suffering in the last moments of animal life.

It is clear that the legal prohibition on causing unnecessary suffering does not apply to instant killings. In the Scottish case of Patchett $v$ Macdougall ${ }^{9}$ the defendant shot and killed a dog but was acquitted of his charge under s1(1)(a) of the Protection of Animals (Scotland) Act 1912 on the basis that there was no direct evidence or expert opinion that the dog had suffered prior to its death. Although his conduct was roundly condemned by the court, they declined to find he had fallen foul of the 1912 Act. As Lord Hunter noted, 'the absence of a positive finding to the effect that the act of the appellant caused the animal suffering is fatal to the conviction'. ${ }^{10}$ In response to a submission by the respondent that the defendant had caused the dog to suffer through depriving it of its life, Lord Wheatley responded, 'Metaphysical considerations apart, I do not consider that the structure and purport of the Act opens the door to that view.' ${ }^{11}$ This position was endorsed, albeit obiter, by the High Court in Isted $v$ DPP 12 in which it was held that a person cannot be convicted for causing unnecessary suffering if an animal is killed outright.

Likewise, s.4(4) of the AWA states that the offence of unnecessary suffering does not include the 'destruction of an animal in an appropriate and humane manner.' Whilst there is scope for interpretation of what constitutes an 'appropriate and humane manner' in this section, it is most plausible to suppose that for somebody to be liable under s.4 it is still essential - as it was prior to the 2006 Act - to demonstrate some degree of suffering:

\footnotetext{
${ }^{5}$ UK law is used as a shorthand for 'the Law of England and Wales'. Scotland and Northern Ireland have separate, although very similar animal protection laws that will not be considered in this article.

${ }^{6}$ Animal Welfare Act 2006, s 4.

${ }^{7}$ The Welfare of Animals at the Time of Killing (England) Regulations 2015 SI 2015/1782, schedules 1-3.

${ }^{8}$ Wildlife and Countryside Act 1981, s 5 \& 11. See also Wild Mammals (Protection) Act 1996, s 1.

${ }^{9}$ (1983) S.C.C.R. 361

${ }^{10}$ ibid, 366.

11 ibid, 364.

12 [1998] Crim LR 194.
} 
'to show only that the defendant was responsible for the death of an animal is not in itself sufficient'. ${ }^{13}$ Accordingly, instant deaths and deaths involving only 'necessary' suffering will not satisfy this requirement.

There are, however, two sets of circumstances where criminal liability can be imposed for causing animal death, independently of considerations of unnecessary suffering. The first is where the animal who is killed is property belonging to another. Under the Criminal Damage Act 1971 (CDA) it is an offence to intentionally or recklessly damage or destroy another's property. Animals who are tamed or ordinarily kept in captivity are included within the definition of property and killing them amounts to destruction of the other's property. ${ }^{14}$ It is obvious that the harm the law is protecting against here is not the harm of death for the animal but the harm of interference with the owner or possessor's property rights. ${ }^{15}$

The second type of animal killing that the law prohibits independently of considerations of suffering are killings of certain protected wild animals and birds. For example, under the Wildlife and Countryside Act it is an offense to kill a wild bird or protected animal.16 This protection covers certain endangered species such as red squirrels, dolphins, snakes, beetles and butterflies. ${ }^{17}$ More common animals, such as foxes and rabbits, are not protected from killing. Again, it is clear from the types of animals that it is prohibited to kill - for example, red squirrels but not grey squirrels - that the objective of the Act is conserving wildlife diversity for anthropocentric reasons rather than for the preservation of animal life qua animal life. ${ }^{18}$

The upshot of this is that these three limitations, clearly grounded upon concerns about the side-effect harms of killing animals, may exhaust UK law's criminal proscriptions against killing animals. ${ }^{19}$ One might think that, given that the killing of animals is so utterly routinised in food production, 'pest' control, scientific experimentation and the like, that a more general prohibition would be unfeasible. I will now show that this is incorrect by demonstrating that other jurisdictions already have such prohibitions.

\footnotetext{
${ }^{13}$ Mike Radford, “"Unnecessary Suffering”: The Cornerstone of Animal Protection Legislation Considered' (1999) Criminal Law Review 702, 704.

${ }^{14}$ Criminal Damage Act 1971 s.10(1)(a).

15 This is made especially apparent when one considers that the CDA provides a defence against a charge of criminal damage where at the time of the act the defendant believed that the person who owned or possessed the property had consented to its destruction or would have so consented if he had known of the circumstances. Thus, where the owner consents - or is believed to have consented - to the killing of their animal property, there is no offence. ibid, s 5(2)(a). ${ }^{16}$ Wildlife and Countryside Act 1981, s 1 \& s 9.

$17 \mathrm{ibid}$, schedule 5 .

${ }^{18}$ Robert Garner refers to this as 'the ideology of anthropocentric conservationism'. Robert William Garner, 'Animal Welfare, Ethics and the Work of the International Whaling Commission' (2011) 7(3) Journal of Global Ethics 279.

${ }^{19}$ I will suggest in s.3(d) that a person responsible for an animal could be liable under s.9 AWA for killing that animal in some instances, even if the death does not cause unnecessary suffering.
} 


\section{KILLING ANIMALS IN OTHER JURISDICTIONS}

As outlined above, the criminal law of England and Wales does not prohibit the killing of animals except in three limited instances. Whilst some other jurisdictions share similarly narrow prohibitions on the killing of animals, there are others that take a more expansive approach. I will now discuss some jurisdictions that adopt broader animal killing offences than the UK.

Italy adopts a slightly broader ban on killing animals. Law n. 281/1991 prohibits veterinarians killing stray cats and dogs unless they are 'seriously or incurably ill or proven to be dangerous'. ${ }^{20}$ This prohibition on killing is independent of whether the death is painful for the animal or whether they are owned by anybody. ${ }^{21}$

Germany and Austria offer more broad-based prohibitions on killing animals. In Austria, it is forbidden to kill animals without 'proper reason'22 and decisions to kill animals in educational settings are subject to the requirement that it is 'indispensable for reaching a particular objective'. ${ }^{23}$ Likewise, in Germany it is an offence to kill a vertebrate animal 'without good reason'. ${ }^{24}$ As with the Austrian law, this leaves considerable room for ethical and legal interpretation. ${ }^{25}$ In practice, good reasons have included all the usual reasons that humans kill other animals: for food, hunting, animal experimentation and so on. ${ }^{26}$ Outside of institutional instances of animal killing, there is scope for this prohibition to curtail the killing of animals. ${ }^{27}$

Turning to the Anglosphere, most State animal cruelty laws in the United States also prohibit the killing of animals in some instances. ${ }^{28}$ Unsurprisingly, these criminal codes

\footnotetext{
${ }^{20}$ See Annamaria Passantino et al, 'Euthanasia of companion animals: a legal and ethical analysis' (2006) 42(4) Ann Ist Super Sanità 491-495.

${ }^{21}$ Eva Voslár ová and Annamaria Passantino, 'Stray dog and cat laws and enforcement in Czech Republic and in Italy' (2012) 48(1) Ann Ist Super Sanità 94, 100 ['captured dogs will be kept in kennels (sanitary kennels or shelters) for a life time at the expense of the town where they were caught']. This prohibition against killing stray cats and dogs does not extend to other animals, nor does it apply if the owner of a cat or dog decides to have them euthanized. The classification of animals as property (res) under the Italian constitution permits the owner the rights to sell or kill the animal as he or she pleases ('ius vitae ac necis').

${ }^{22}$ Federal Act on the Protection of Animals ('Bundesgesetz über den Schutz der Tiere') 2004, § 6 (1) Of course, what constitutes a 'proper reason' is contentious, but unsurprisingly, the legislation makes it clear that the skilled, professional killing of animals for food, education, training, 'pest' control or euthanasia are not within the ambit of the prohibition. ibid, $\S$ 6 (1) (4). Nevertheless, outside of such professional settings there is a general prohibition in place against killing of animals that is lacking in the UK.

${ }^{23} \mathrm{ibid}$, § 6 (1) (3) For contrast, in the UK all that is required for the killing of an animal used in a scientific procedure is that it conforms to 'the appropriate methods of humane killing'. See Animals (Scientific Procedures) Act 1986, schedule 1.

${ }^{24}$ Animal Protection Act ('Tiershutzgesetz') 1972, art. 17(1).

${ }^{25}$ Indeed, this provision was intentionally drafted vaguely so as to leave room for interpretative openness with regard to developments in research, knowledge and evolving societal attitudes. See Kate M. Nattrass, ““...Und Die Tiere” Constitutional Protection for Germany’s Animals' (2004) 10 Animal Law 283, 289.

${ }^{26} \mathrm{ibid}$.

${ }^{27}$ For example, the German Animal Protection League has used this law as the basis for its shelter regulations by which no animal may be euthanised due to lack of space or inability to find a home, ibid.

${ }^{28}$ Animal cruelty is defined variously as including where somebody 'maliciously and intentionally kills an animal', 'needlessly kills an animal', 'kills without need any animal other than insects, vermin, or other pests', the 'intentional and
} 
have various qualifiers and exemptions to these prohibitions that function in a comparable way to the qualifiers and exemptions in Austrian and German law. ${ }^{29}$ In New South Wales, animal cruelty is defined as including 'any act or omission as a consequence of which the animal is unreasonably, unnecessarily or unjustifiably... killed'. ${ }^{30}$

Finally, a more radical approach was proposed in the Indian city of Palitana. In 2014 200 Jain monks engaged in a hunger strike as part of a campaign to convert the city into a 'vegetarian town'. ${ }^{31}$ On August 2014, the Gujarat state government reportedly acceded to these demands, enacting a local law banning the buying and selling of meat and prohibiting all slaughter of animals within the city boundaries. ${ }^{32}$

The purpose of this section has been to demonstrate that a variety of alternatives to the British position on the killing of animals exist, not merely theoretically, but as a present legal reality. Of course, the fact that a range of legal approaches exist does not inform us as to which is most preferable. Moreover, comparative legal evaluation is riddled with complexity: the specific political, social, economic, cultural, religious, demographic, ethnic, historical and constitutional contexts of different jurisdictions make it notoriously tricky to import legal norms from one to another. Rather than taking inspiration from elsewhere to assess the desirability of the current UK position on the killing of animals, I will base this evaluation on two widely accepted norms within our own legal culture: (1) the independent value of animal welfare and (2) the harm principle as a basis for criminalisation. Both of these norms support an extension of criminal liability with respect to killing animals. In the next section I turn to the first of these arguments.

\section{ANIMAL DEATH AND ANIMAL WELFARE}

Hitherto, UK legislation has not treated animal death as a welfare issue but rather as a 'post-welfare' issue. ${ }^{33}$ In this section I will argue that this position is untenable, particularly against the backdrop of the emergence of a holistic welfarist paradigm underpinning UK animal protection law. To support this claim, I will begin by noting

\footnotetext{
malicious infliction of... death upon an animal' and other similar variants. See Cal. Penal Code $\S \S 286.5,597$, CO Rev Stat $\S 18-9-202$, HI Rev Stat $\S 711-1109$ (c) (2016) and Idaho Title 25, Chapter 35, 25-3501 et seq respectively.

${ }_{29}$ To give one example, the Delaware Statute exempts 'killing of any animal normally or commonly raised as food for human consumption, provided that such killing is not cruel'. Del. Code Ann. Tit. 11, § 1325(b)(4).

${ }^{30}$ Prevention of Cruelty to Animals Act 1979, s.4(2)(a).

${ }^{31}$ Andrew Buncombe, 'The Vegetarian Town: They wouldn't Hurt a Fly but the Jains Upset Palitana with Meat-free Plea', Independent, 6 July 2014.

32 Saeed Khani, 'Gujarat HC Seeks Reply over Banning Sale of Non-veg Food in Palitana', Times of India 16 September 2014. The motivation behind this law was the central Jainist tenant of ahimsa: a rejection of violence against all living beings. See Ruben van Popering, 'Jain Vegetarian Laws in the City of Palitana: Indefensible Legal Enforcement or Praiseworthy Progressive Moralism?’ (Master’s Thesis, Linköping University 2015) 6.

${ }^{33}$ T J Kasperbauer and Peter Sandøe, 'Killing as a Welfare Issue' in Tatjana Visak and Robert Garner (eds) The Ethics of Killing Animals (OUP 2016) 23.
} 
three interconnected shifts that have occurred in UK animal protection law over the last two centuries: (1) the shift from protecting animal interests instrumentally to protecting them for their own sake; (2) the shift in the focus of animal protection from 'anti-cruelty' to 'welfare' and; (3) the more recent partial shift from a focus on negative welfare to holistic welfare. I will then argue that a logical extension of these developments is to provide more stringent legal protection of animals against killing at the hands of humans.

\section{(a) From indirect protection to direct protection}

As Walters J of the Supreme Court of Oregon has observed, 'we do not need a mirror to the past or a telescope to the future to recognise that the legal status of animals has changed and is changing still'. ${ }^{34}$ This remark is as apt in the UK and European contexts as it is of the US. In the past, animals were not regarded as worthy of any direct protection by law. A popular English jurisprudence textbook published in 1947 described the legal status of animals in the following way:

'A beast is as incapable of legal rights as of legal duties, for its interests receive no recognition from the law... The law is made for men, and allows no fellowship or bonds between them and the lower animals. If these last possess moral rights... these rights are not recognised by the legal system.' ${ }^{35}$

Such attitudes reflected prevalent religious and ethical positions towards animals stretching back to antiquity which appealed to divine providence to justify human domination and ownership of the other creatures. Thinkers such as Aristotle, and later St Thomas Aquinas, asserted that the universe had been designed hierarchically with 'nonrational' animals existing to serve 'rational' humans, justifying our 'unlimited dominion' over them. ${ }^{36}$ These ideas percolate into modern legal discourse especially via the writings of Locke and Blackstone, both of whom justified the subordinate status of animals on theological grounds. ${ }^{37}$ Philosophers such as Kant gave a secular twist to these arguments, claiming that animals' inability to determine their own autonomous ends means that

\footnotetext{
${ }^{34}$ State v. Fessenden/Dicke 355 Or 759 (2014) 769-770.

${ }^{35}$ Glanville Williams, Salmond on Jurisprudence (Sweet and Maxwell, 10 $0^{\text {th }}$ ed, 1947) 319.

${ }^{36}$ Aristotle, 'Politics' in William Ellis (trans), The Politics of Aristotle (Dent 1912) 1254b2-6b12; St Thomas Aquinas,

'Summa Theologica' in Fathers of the English Dominican Providence (trans) The Summa Theologica of St Thomas Aquinas (Burns, Oates and Washbourne, $2^{\text {nd }}$ ed, 1922) Question 96.

37 John Locke, 'The Second Treatise of Government' in John Locke, Two Treaties of Government (CUP 1988) 270-271;

William Blackstone, Commentaries of the Laws of England Volume 2 (University of Chicago Press 1979) 2.
} 
humans owe them no direct moral obligations and can use them as instruments for their purposes. ${ }^{38}$

Although thinkers like Aquinas, Locke and Kant did not believe that humans owed any direct moral duties to animals, they were all against animal cruelty because they believed that it would have undesirable side-effects for intra-human relations, most notably in its propensity to coarsen our attitudes toward one another. ${ }^{39}$ As Kant put it: 'Our duties towards animals are merely indirect duties towards humanity... he who is cruel to animals becomes hard also in his dealings with men'. ${ }^{40}$ This perspective - which has been dubbed the 'indirect duty' view ${ }^{41}$ - had formidable influence on early animal protection laws. Predominant motivations for early $19^{\text {th }}$ century anti-cruelty legislation included the maintenance of social order, the deterrence of crime and the aversion of moral corruption. Concern for animal wellbeing was often a secondary consideration, if considered at all. ${ }^{42}$ As the jurisprudence text book quoted above put it: "That which is done to the hurt of a beast may be a wrong to its owner or to the society of mankind, but it is no wrong to the beast.' 43

As scientific understanding and moral and religious sentiment towards animals has shifted, the view that animals possess no direct moral status requiring reflection in the law has become untenable. As early as the late $18^{\text {th }}$ century, Bentham decried that, before the law, the other animals 'stand degraded into the class of things'. ${ }^{44} \mathrm{He}$ pointed out that animals, unlike inanimate objects, are conscious creatures who experience pleasure and pain. Their lack of 'rationality' is not grounds for ignoring their interests: 'the question is not, Can they reason? nor, Can they talk? but, Can they suffer?'45

\footnotetext{
${ }^{38}$ Immanuel Kant, Ethical Philosophy: The Complete Texts of Grounding for the Metaphysics of Morals, and Metaphysical Principles of Virtue, Part II of The Metaphysics of Morals, with On a Supposed Right to Lie Because of Philanthropic Concerns (Hackett Publishing 1994) 35-36.

${ }^{39}$ See St. Thomas Aquinas, 'Summa contra Gentiles' in Anton C. Pegis (trans) Basic Writings of Thomas Aquinas (Random House 1945) cited in Andrew Linzey, Why Animal Suffering Matters: Philosophy, Theology and Practical Ethics (OUP 2009) 86; John Locke, 'Some Thoughts Concerning Education' (1693) published in John Locke, The Works of John Locke in Nine Volumes: Vol. 9 (W. Otridge and Son 1812) 112; Immanuel Kant, 'Duties Towards Animals and Spirits' in Immanuel Kant, Lectures on Ethics (Harper \& Row 1963) 239-240.

${ }^{40}$ Kant, ibid 240.

${ }^{41}$ Tom Regan, The Case for Animal Rights (University of California Press 2004) 150.

${ }^{42}$ Radford (n 3) 52-59; Edward Westermarck, The Origin and Development of the Moral Ideas Vol. 2 (Macmillan 1917) 508509 [commenting on the anthropocentric bases of early attempts to outlaw bearbaiting]. See the preamble to the Cruelty to Animals Act 1835 which included concern for 'Accidents [that] arise from improperly driving Cattle', 'the Demoralization of the People' 'the Lives and Property of His Majesty's Subjects' and described the settings for animal fights as 'Places idle and disorderly Persons commonly assemble'. Cruelty to Animals Act 18355 \& 6 Will. 4, c. 59, preamble. See also Re Wedgewood [1915] 1 Ch. 113, 122 where Swinfen Eady LJ, in considering whether giving a gift to an animal charity should be considered a charitable donation, reasoned that it was because acts of kindness towards animals 'promote the feelings of humanity and morality generally, repress brutality, and thus elevate the human race'.

${ }^{43}$ Williams (n 35) 319. For a similar stance in the US context, see Louis B. Schwartz, 'Morals, Offenses and the Model Penal Code' (1963) 63 Columbia Law Review 673.

${ }^{44}$ Jeremy Bentham, An Introduction to the Principles of Morals and Legislation (Dover 2007) 311.

45 ibid.
} 
The Benthamite view concerning the moral salience of animal sentience has played an important role in re-moulding Western legal systems to give direct protection to animal interests, ${ }^{46}$ and in determining which animals ought to be protected. For example, the animals protected under the Animals (Scientific Procedures) Act 1986 and the AWA are 'vertebrates other than man'. ${ }^{47}$ As the explanatory notes to the AWA make clear, this is because 'these are currently the only demonstrably sentient animals'. ${ }^{48}$ Moreover, s1(3) makes provision for the appropriate national authority to extend the Act to cover invertebrates in the future if they are satisfied on the basis of scientific evidence that these too are capable of experiencing pain or suffering. ${ }^{49} \mathrm{It}$ is clear that the basis for UK animal welfare law today is that animals possess sentience and that this sentience in turn gives us direct duties towards them.

Furthermore, Britain's animal welfare laws cannot be understood without reference to the broader framework of EU law it operates under. ${ }^{50}$ When the Lisbon Treaty came into force in 2009 it amended the 'Treaty on the Functioning of the European Union' (TFEU) and introduced the recognition that animals are sentient beings. Article 13 of Title II states that:

In formulating and implementing the Union's agriculture, fisheries, transport, internal market, research and technological development and space policies, the Union and the Member States shall, since animals are sentient beings, pay full regard to the welfare requirements of animals.... ${ }^{51}$

Member States are thus required to have regard for the 'welfare interests of animals' on the basis that they are 'sentient beings'. Even more strikingly, paragraph (12) of the recitals to the subsequent Directive 2010/63/EU concerning the protection of animals used for scientific purposes provides further evidence that modern animal welfare is based

\footnotetext{
${ }^{46}$ A number of jurisdictions have recently expressly recognised animals as sentient beings within their animal protection legislation. In 1997 Polish law recognised that 'an animal is not a thing, but a living creature capable of suffering'. Polish Act on the Protection of Animals, art 1. In 2015 New Zealand's Animal Welfare Act 1999 was amended to 'recognise that animals are sentient'. Animal Welfare Amendment Act (No 2) 2015, s4. In 2015 The French Code Civil was amended to define animals as 'living creatures endowed with sensitivity'. For a discussion of this see Jean-Marc Neumann, 'The Legal Status of Animals in the French Civil Code' (2015) Global Journal of Animal Law 1.

${ }^{47}$ Animal Procedures Act 1986, s1(1); Animal Welfare Act 2006, s.1(1).

${ }^{48} \mathrm{ibid}$, Explanatory Note 11. See also the then Secretary of State for Environment, Food and Rural Affairs, Margaret Beckett's explanation during the second reading of the legislation. HC Hansard, 10th January 2006, cols. 163-4.

${ }^{49}$ Subsequently, on the basis of scientific evidence, protection has been extended to cephalopods in the context of animal experimentation via EU Council Directive 2010/63/EU, 2010 O.J. (L 276), 3(b).

${ }^{50}$ Around $80 \%$ of UK animal welfare laws originate from the EU. See RSPCA 'The EU Referendum: The Relevance of Welfare' (2016) <http://www.rspca.org.uk/webContent/staticImages/EUReferendumBriefing.pdf $>$ accessed 14 August 2018. ${ }^{51}$ Treaty of Lisbon Amending the Treaty on European Union, the Treaties Establishing the European Communities, Dec. 13, 2007, 2007 O.J. (C 306) 49, art.2 (21).
} 
upon the intrinsic value animals: 'Animals have an intrinsic value which must be respected... animals should always be treated as sentient creatures'. ${ }^{52}$

Moreover, the UK's express commitment to the significance of animal sentience appears to have been strengthened rather than diminished as a result of the ongoing 'Brexit' saga and prospective withdrawal from the EU. Michael Gove, the present Secretary of State for Environment, Food and Rural Affairs, has insisted that the 'sentience of animals will continue to be recognised and protections strengthened when we leave the EU'. In December 2017 Gove introduced the Animal Welfare (Sentencing and Recognition of Sentience) Draft Bill which 'explicitly recognises that animals are sentient beings and places a duty on Ministers of the Crown to have regard to their welfare needs when formulating and implementing government policy. ${ }^{53}$ If this bill passes into legislation, it will embed the principle that animals ought to be protected on account of their sentience more clearly than ever before in domestic law.

From the preceding analysis it is should be clear that contemporary animal welfare standards in England and Wales, and Europe more widely, have animals as their intended beneficiaries and the protection of animal welfare is no longer merely the derivative outcome of other goals.

\section{(b) From anti-cruelty to welfare}

The aforementioned shift from the indirect duties view to the direct duties view has also given rise to a shift in the focus of animal protection legislation from anti-cruelty to welfare. Because the indirect duty view that undergirded early animal protection legislation was concerned primarily with averting the moral corruption of humans engaged in animal abuse, it generally targeted acts of wanton cruelty and was framed in terms of prohibiting acts of brutality such as beating, abusing, ill-treating, torturing and baiting. ${ }^{54}$

However, in the $20^{\text {th }}$ century, the courts moved away from a focus on wanton cruelty and gravitated instead towards the causing of unnecessary suffering. In Barnard $v$ Evans 'cruelty' and 'causing unnecessary suffering' were essentially found to be legal synonyms. ${ }^{55}$ Throughout the century, animal welfare law shifted its focus away from acts

\footnotetext{
${ }^{52}$ EU Council Directive 2010/63/EU, 2010 O.J. (L 276), recitals para. (12).

${ }^{53}$ Animal Welfare (Sentencing and Recognition of Sentience) Draft Bill (2017), 14.

${ }^{54}$ See e.g. Cruelty to Animals Act 1849 , s2.

${ }^{55}$ Barnard v Evans [1925] 2 K.B. 794, 798 (per Sherman J.).
} 
of sadism towards prohibiting acts or omissions causing unnecessary suffering to animals. ${ }^{56}$

A catalyst for an upsurge of concern for animal welfare was the publication of Ruth Harrison's 1964 book Animal Machines: an exposé and critique of intensive animal farming practices. ${ }^{57}$ The outcry in response to this book led the British government to appoint a committee to look in to the welfare of farm animals. This committee published the Brambell Report, a milestone in the discussion of animal welfare and the obligations that we owe to farm animals in particular. ${ }^{58} \mathrm{~A}$ few years later, the Agriculture (Miscellaneous Provisions) Act 1968 came into effect. The 1968 Act provided for the promulgation of regulations with respect to the welfare of farmed animals, including in respect of accommodation, provision of food and water, handling practices and so forth. ${ }^{59}$ It was the first major piece of legislation that "moved beyond simply regulating cruelty and created a positive regulation-making power to promote the welfare of animals. ${ }^{60}$

In the following decades, a cascade of statutes, regulations, codes of conduct and EU directives set welfare standards - with varying degrees of sophistication - across a broad range of areas including farming practices, scientific procedures, pet shops, zoos and circuses. ${ }^{61}$ A number of practices were outlawed on the grounds that they were regarded as inflicting unnecessary suffering on animals, including scientific experiments on great apes, ${ }^{62}$ veal crates in the dairy industry, ${ }^{63}$ tethers and close-confinement stalls for breeding sows, ${ }^{64}$ hunting wild mammals with dogs, hare coursing, ${ }^{65}$ conventional battery cages, ${ }^{66}$ leghold traps ${ }^{67}$ and cosmetics testing on animals, ${ }^{68}$ to name a few examples. None of these practices (with the possible exception of hunting) involve inflicting suffering for sadistic reasons, but rather for pursuing instrumentalist goals such as profit or research. Nevertheless, societal attitudes have evolved - albeit selectively - to value animal welfare

\footnotetext{
${ }^{56}$ See e.g. Waters $v$ Braithwaite (1913) 78 JP 124 [holding that taking a cow to market in an un-milked state constituted causing unnecessary suffering]; Hall $v$ RSPCA (Unreported) November 11, 1993 [holding a pig farmer liable for failing to seek veterinary advice for their pigs], QBD; RSPCA v Isaacs [1994] Crim L.R 517 [holding a dog owner liable for the failure to consult a veterinary surgeon].

${ }^{57}$ Ruth Harrison, Animal Machines (Stuart 1964).

${ }^{58}$ Francis W.R Brambell, Report of the Technical Committee to Enquire into the Welfare of Animals Kept in Intensive Livestock Husbandary Systems (H.M Stationery Office 1965).

${ }^{59}$ Agriculture (Miscellaneous Provisions) Act 1968, s.2.

${ }^{60}$ Margaret Beckett, HC Hansard, cols 161-162 10th January 2006.

${ }^{61}$ See Radford (n 3) 289-316.

${ }^{62}$ Animals (Scientific Procedures) Act 1986, 5C (5).

${ }^{63}$ Welfare of Calves Regulations 1987, SI 1987/2021.

${ }^{64}$ See House of Commons Environment, Food and Rural Affairs Committee The English pig industry First Report of Session 2008-09 HC 96 Incorporating HC 1088, Session 2007-08, para.35; Council Directive 2008/120/EC, 2008 O.J. (L 45) 5 .

${ }^{65}$ Hunting Act 2004.

${ }^{66}$ Council Directive 1999/74/EC 1999 O.J (L203).

${ }^{67}$ Council Regulation 3254/91, 1991 O.J. (L 308)

${ }^{68}$ Council Regulation 1223/2009, 2009 O.J. (L 342).
} 
as an independent good and judge certain practices which adversely affect it to be wrongful, regardless of the motives of the persons engaging in these practices, and this is reflected, partially at least, in our legal regime.

A watershed moment in the shift from anti-cruelty to welfare was the passing of the AWA in 2006. The previous year in October 2005 the Government published the Animal Welfare Bill. The press release accompanying the Bill stated:

We are raising standards of animal welfare. Anyone who is responsible for an animal will have to do all that is reasonable to meet the needs of their animal...This is a much more appropriate way to ensure an animal's welfare than relying on a 94-year-old law that was only designed to prevent outright cruelty. ${ }^{69}$

The AWA introduced the most significant changes to animal welfare legislation in almost a century, recognising that individuals in charge of animals have a responsibility to protect them from more than just overt cruelty. The Act focuses more broadly on the conditions in which animals are kept and places a duty of care on those who keep them to provide a minimum standard of care. ${ }^{70}$ It extended the positive regulation-making powers contained in the provisions in the Agriculture (Miscellaneous Provisions) Act to all domesticated and captive animals. ${ }^{71}$ It expunged language associated with wanton cruelty - such as beating, torturing, tormenting, terrifying and so forth - that featured in earlier animal protection laws ${ }^{72}$ and instead uses neutral language relating to causing suffering and failing to ensure welfare.

It appears that not only has the legal status of animals shifted over the last couple of centuries, but also that over the course of the last 100 years there has been a refocusing of the basis for animal protection law from prohibiting outright cruelty to promoting and ensuring animal welfare through the adoption of best practices.

\section{(c) From negative to holistic welfarism}

Animal protection law's focus is now on welfare. This gives rise to the issue of how welfare is understood. Welfare as a concept has evolved over time, particularly in the animal context. Traditional discussions of animal welfare have tended to focus on the absence of negative states such as pain, frustration, boredom and fear, but recently there has been increased consideration of positive mental states such as satisfaction, joy and pleasure. ${ }^{73}$

\footnotetext{
${ }^{69}$ Defra, 'Raising the standards of animal welfare: new Bill published' News Release 449/05, 14 October 2005.

${ }^{70}$ Animal Welfare Act (n 6), s.9.

71 ibid, s. 2 \& s. 12.

${ }^{72}$ See e.g. Animal Protection Act 1911, s 1(1).

${ }^{73}$ Kasperbauer and Sandøe (n 33) 18.
} 
The traditional focus on negative states can be in seen in the responses to the Brambell report. Over the last 40 years, the so-called 'Five Freedoms' have become an important set of guidelines for the welfare of animals under human control. The concept of the five freedoms was implicit in the Brambell report but subsequently the idea was refined greatly and adopted in 1979 by the UK Farm Animal Welfare Council (UKAWC). ${ }^{74}$ The five freedoms identified by the UKAWC are: freedom from hunger and thirst; freedom from discomfort; freedom from pain, injury and disease; freedom to express normal behaviour and; freedom from fear and distress. ${ }^{75}$ These five freedoms have since achieved public recognition worldwide and underscore national legislation and marketing and farm assurance schemes, sometimes with minor modifications. ${ }^{76}$

The freedoms set out by UKAWC can be described as negative freedoms, i.e. the absence of undesirable experiences. ${ }^{77}$ The skewed focus on the importance of avoiding negative states is understandable given the urgency and gravity of addressing the massive pain and suffering that was being endured, and still is, by animals on factory farms. However, whilst the avoidance of negative states is a necessary component of an animal welfare ethic, it is not sufficient to capture what animal welfare protection ought to achieve. As Kasperbauer and Sandøe point out, what we might term negative welfarism gives rise to counter-intuitive conclusions: 'If avoiding suffering was all that mattered, then every animal should be killed as soon as possible, since this would ensure the absence of suffering'. ${ }^{78}$ This is implausible, and surely points, as Kasperbauer and Sandøe suggest, toward a welfare paradigm that is concerned with the balance of positive and negative states. ${ }^{79}$ After all, animal sentience implies not merely the capacity to suffer, but also the ability to have pleasurable experiences in relation to, for example, play, sex, touch, food, anticipation, comfort and aesthetics. ${ }^{80}$ Just as it is bad for animals to have negative experiences, it is also bad if they are denied positive experiences.

Indeed, these are observations that the UKAWC themselves came to embrace. In a 2009 report they argued that the goals of animal welfare need to move beyond the five

\footnotetext{
${ }^{74}$ Farm Animal Welfare Council, Report on Farm Animal Welfare in Great Britain: Past, Present and Future (12 October 2009) 2, para.6. <https://www.gov.uk/government/publications/fawc-report-on-farm-animal-welfare-in-great-britain-pastpresent-and-future $>$ accessed 14 August 2018.

${ }^{75}$ Farm Animal Welfare Council 'Press Statement' (5 December 1979) archived at

$<$ http://webarchive.nationalarchives.gov.uk/20121010012427/http://www.fawc.org.uk/freedoms.htm> accessed 14 August 2018)

${ }^{76}$ Farm Animal Welfare Council (n 74) 2, para. 6.

${ }^{77}$ Even the notion 'normal behaviour' is largely understood in negative terms as 'behaviour that is not abnormal; stereotypic and other abnormal behaviours such as tail chewing are undesirable and a sign of poor welfare'. Farm Animal Welfare Council (n 74) 2, para.7.

${ }^{78}$ Kasperbauer and Sandøe (n 33) 19.

${ }^{79}$ ibid 20

${ }^{80}$ See generally Jonathan Balcombe, Pleasurable Kingdom: Animals and the Nature of Feeling Good (St Martin's Press 2006); Marc Bekoff, The Emotional Lives of Animals (New World Library 2007).
} 
freedoms'. ${ }^{81}$ Instead of focusing solely on the absence of suffering, they recommended that 'policy moves... to ensuring an acceptable quality of life over an animal's lifetime.' ${ }^{2}$ Thus, while it is important to prevent suffering and cruelty 'the requirement to provide for an animal's needs in the new Animal Welfare Acts implies that good welfare should be an ambition too.' 83

For our purposes what is of most relevance here is the UKAWC's assertion that the new legal requirements set out under the AWA give rise to a broader ethic of animal welfare, something we might term holistic welfarism, i.e. a concern with the balance of positive and negative states. Most relevant here is the animal welfare offence set out under s.9 of the AWA. Under this section a person commits an offence if he does not take reasonable steps 'to ensure that the needs of an animal for which he is responsible are met to the extent required by good practice'. S.2 sets out a list of animal needs for the purposes of the Act:

(a) its need for a suitable environment,

(b) its need for a suitable diet,

(c) its need to be able to exhibit normal behaviour patterns,

(d) any need it has to be housed with, or apart from, other animals, and

(e) its need to be protected from pain, suffering, injury and disease.

It is clear that these identified needs are based in part on the five freedoms, but it should be noted that, whereas the five freedoms are expressed negatively as freedom from negative states, the needs set out under s.9 - with the exception of (e) - are framed in positive terms such as 'need for' or 'need to'. This framing shifts the focus from avoiding suffering to promoting welfare. Indeed, this was the raison d'être of the s.9 offence. As the then Secretary of State for Environment, Food and Rural Affairs made clear during the bill's second reading, the purpose of the new general offence was to address an anomaly:

there are cases where, although animals are perhaps not yet suffering, their welfare needs are not being met. Action in such circumstances can currently be taken only against owners of farm livestock. For other captive and domestic animals, the owner can only be invited to take action. ${ }^{84}$

\footnotetext{
${ }^{81}$ Farm Animal Welfare Council, (n 74) ii.

82 ibid, letter to Hilary Benn MP.

${ }^{83}$ ibid, 2 para. 7.

${ }^{84}$ Margaret Beckett, HC Hansard col 16610 January 2006.
} 
In order to be liable under s.9 it is thus not necessary to establish that an animal is suffering, merely that their welfare needs are not being met. This is particularly seen in some of the Codes of Practice that have been issued under s.14 of the 2006 Act. For example, under the Code of Practice for the Welfare of Dogs there is guidance that explicitly concerns enhancing dogs' quality of life:

most dogs are playful, sociable animals and they enjoy playing together with toys, people and other dogs. Play is an important part of getting along with people and other dogs... Dogs are sociable animals that need, and enjoy, company... if a dog has appropriate contact with other dogs early in its life it will be more sociable and this can enhance its quality of life. ${ }^{85}$

Similar guidance has also been issued in relation to cats and equidae animals. ${ }^{86}$ What these codes illustrate - even if inconsistently between different species of animal and not translated into concrete legal duties - is an underlying ethos of concern for animal welfare under human control, not merely the absence of suffering. The next section will consider the implication of this shift to the question of animal death.

\section{(d) Holistic welfare and death}

The emergent holistic welfarist paradigm in UK animal protection law is concerned not only with avoiding unnecessary suffering but also insuring that protected animals have, at the least, a basic quality of life. It is concerned with the presence of animal pleasure as well as the absence of animal pain.

The implication that this has for the killing of animals should be obvious: the killing of animals is a welfare issue because premature death potentially deprives an animal of a future life worth living. If we think that it is prima facie wrong to deprive animals of the pleasures of life when they are alive, then we surely ought also to think that it is prima facie wrong to deprive them of a life containing pleasure: both involve a deprivation of the goods of life.

Of course, it will often be possible to bring a prosecution for the killing of an animal on the basis that the death involved 'unnecessary suffering'. ${ }^{87}$ However, there are two reasons for thinking this is not the ideal way to prosecute such cases. First, the requirement that the prosecution must prove beyond reasonable doubt that the animal

\footnotetext{
${ }^{85}$ Defra, Code of Practice for the Welfare of Dogs (Department of the Environment, Food and Rural Affairs 2009), 4-5.

${ }^{86}$ Defra Code of Practice for the Welfare of Horses, Ponies, Donkeys and their Hybrids (Department of Food and Rural Affairs 2009); Defra, Code of Practice for the Welfare of Cats (Department of Food and Rural Affairs 2013).

${ }^{87}$ See e.g. Gray \& Gray v Crown Court Aylesbury \& RSPCA [2013] EWHC 500 (Admin) (finding the defendant liable for causing unnecessary suffering by letting animals under his care die).
} 
suffered before dying will often be difficult to establish, as was seen in the case of Patchett discussed in part 1.

Second, there is a fair labelling reason for charging a defendant with a separate of offence of killing an animal rather than relying on the unnecessary suffering offence. The crime that a defendant is charged with should reflect the gravity of the wrongdoing committed. It is contended here that classifying the killing of an animal simply as the causing of unnecessary suffering fails to capture the full extent of the harm caused.

For these reasons, it would be desirable if animal protection law was developed to include a separate offence of animal killing. This could be formulated similarly to one of the animal killing offences from other jurisdictions discussed in part 2 or it could take a novel form.

As an aside, there is also scope for an argument to be made that a person responsible for an animal could already be liable for killing that animal, even if that killing is painless, on the basis of the s.9 welfare offence under the AWA. S9(4) states that 'Nothing in this section applies to the destruction of an animal in an appropriate and humane manner.' 88 The wording of this section is identical to that of s.4(4), discussed in part 2. It was argued that in the context of s.4, this exclusion clause means killing that does not cause an animal unnecessary suffering will not amount to causing unnecessary suffering. This is in line with the Pre-2006 case law concerning the killing of animals.

By contrast, in the context of s.9, what constitutes 'appropriate and humane' arguably assumes a different meaning. Whilst we can take 'humane' to mean avoiding unnecessary suffering, 'appropriate' should be understood both in light of s. 9 and its plain and ordinary meaning. S.9 is concerned with providing for the welfare needs of an animal. From a holistic welfare perspective these welfare needs include continued life, provided that it has the possibility for pleasurable experiences within it. Therefore, to deprive an animal of a life worth living is a prima facie interference with that animal's needs and welfare. For something to be appropriate it is 'suitable or proper in the circumstances'. Whether any given conduct is appropriate is measured against societal norms and mores. If certain forms of killing of animals are not deemed societally appropriate, for example the shooting of a pet dog, then it is argued that they do not fall within the s.9(4) exclusion clause and may still be subject to criminal sanction, even in the absence of any proof of suffering. ${ }^{89}$

\footnotetext{
${ }^{88}$ Animal Welfare Act 2006, s.9(4).

${ }^{89}$ Using s.9 to hold a person liable for killing animals would be a defensible reading of the law, but it is not an ideal way to prosecute killing offences. Liability under s.9 only applies to those responsible for an animal. This means that those who do not bear such responsibility cannot be held liable. For this reason, it would be preferable for a new offence to be created to deal specifically with the unlawful killing of an animal.
} 
This section has argued that UK animal protection law regards animals as possessing independent value and interests that ought to be protected. Given that death deprives animals of the possibilities for future good experiences, it should be regarded as a prima facie interference with that animal's welfare and, in the absence of a compelling reason, ought to be the grounds for criminal liability.

\section{(e) A qualification}

The above account of the evolution of animal welfare law in the UK could be read as painting far too rosy a picture of the state of the law today. There are a number of problems with the law - both substantive and in its enforcement - that undermine its ability to provide adequate protection to many animals. First, the utilitarian balancing act at the heart of determining what constitutes 'unnecessary suffering' 90 has tended to give undue weight to human interests, especially their economic interests. ${ }^{91}$ Correspondingly, insufficient consideration is often given to animal interests, particularly those of 'food' animals. ${ }^{92}$ Thus, what constitutes improper harm to animals as well as adequate care 'continues to be understood primarily in terms of the interests of humans. And our privileged position invariably governs. ${ }^{93}$

Second, the laws that do exist are often under-enforced. Data released by the Food Standards Agency in 2016 revealed a total of 9,511 animal welfare breaches inside abattoirs between July 2014 and June 2016. These included chickens being boiled alive and animals suffocating or freezing to death in trucks. ${ }^{94}$ This lack of effective enforcement is attributed to several causes 'ranging from insufficient funding to failing to take the rights of animals seriously'. ${ }^{5}$

\footnotetext{
${ }^{90}$ See Ford $v$ Wiley (1889) 23 QBD 203, 210 (setting out a 'balancing exercise' weighing human and animal interests in determining whether animal suffering is unnecessary).

${ }^{91}$ Gary L. Francione, Animals, Property and the Law (Philadelphia: Temple University Press 1995) 17-32.

92 This is reflected in the various regulations and codes of practice that govern the treatment of 'livestock'. These permit close confinement, mutilation without aesthetic, and various other harmful practices that comprise industrial 'factory farming'. See e.g. The Welfare of Farmed Animals (England) Regulations 2000 (S.I. 2000 No. 1870); The Welfare of Farmed Animals (England) Regulations 2007 (S.I 2007 No. 2078). For a critique see Compassion in World Farming, 'In Defence of Factory Farming: How a Ruinous System is Kept Afloat' (n/d) <https://www.ciwf.org.uk/media/7044323/in-defence-of-factory-farming-how-a-ruinous-systemis-kept-afloat.pdf $>$ accessed 14 August 2018.

93 Reece v. Edmonton (City), 2011 ABCA 238 [61] per Chief Justice Fraser (dissenting).

${ }^{94}$ Andrew Wasley and Josh Robbins, 'FSA: 4,000 major breaches of animal welfare laws at UK abattoirs in two years' (Guardian, 28 August 2016).

95 Reece v. Edmonton (City) n 93 above [62]
} 
Third, animals lack the status of 'persons', ${ }^{96}$ meaning that efforts by citizens or advocacy groups to protect their interests are undermined by denying legal standing to them and the animals they seek to protect. 97

That being said, despite these very real structural deficits in our animal welfare law themselves symptomatic of broader inconsistencies in societal moral attitudes towards animals ${ }^{98}$ - the preceding analysis has attempted to demonstrate that there is an aspirational ethos underpinning the law that regards animals and their welfare as worthy of protection. ${ }^{99}$ In some areas this ethos has translated into notable improvements in the lives of animals, particularly animals kept as pets and some wild animals. In other areas, such as animals used for food or medical research, the law has been less effective in improving the quality of their lives.

Under present social arrangements it is inconceivable that an animal killing offence would not also be applied with the same degree of normative inconsistency as our current welfare laws are. There are some domains where animals are generally regarded as expendable - particularly food animals, who are bred to be killed - and this would be reflected in the law as long as it is socially accepted. ${ }^{100}$ But just as it is better to have limited and inconsistent legal protections for animals whilst they are still alive than none at all, it is also better to have limited and inconsistent legal protections for animals against being killed than none at all.

In summary, this section has argued that UK animal protection law regards animal welfare as independently valuable. This, I have argued, has the implication that it ought to also protect animals against killing in some instances. In the next section I will provide a second, complimentary line of argumentation in favour of the introducing an animal killing offence. This argument is based on the liberal account of the legitimate basis for criminalisation that has become known as the 'harm principle'.

\footnotetext{
${ }^{96}$ See Moosun and Ors $v$ HSBC Bank PLC [2015] EWHC 3308 (ruling that a civil claim could not be brought on behalf of two dogs).

97 Steven M. Wise, 'Legal Personhood and the Nonhuman Project' (2010) 17(1) Animal Law 1.

${ }^{98}$ Gary Francione describes, with justification, our contradictory attitudes towards animals as exhibiting a "moral schizophrenia". Gary L Francione, Introduction to Animal Rights: Your Child or the Dog? (Philadelphia: Temple University Press, 2000) 1.

${ }^{99}$ For an account of the idea of 'aspirational law' See Philip Harvey, 'Aspirational Law' (2004) 53 Buffalo Law Review 101.

${ }^{100}$ As Francione puts it: 'Until a larger segment of society accepts, for example, that our enjoyment of the taste of meat does not -- cannot, as a moral matter -- justify killing animals for food, legal change for animals will necessarily be limited.' Gary Francione, 'Animals as Property' (1996) 2 Animal Law.
} 


\section{ANIMALS AND THE HARM PRINCIPLE}

Within the Anglosphere, the harm principle is commonly regarded as at least a useful starting point for thinking about the role of the criminal law in a liberal democracy. ${ }^{101}$ Bernard E. Harcourt has argued that it has become normatively hegemonic as the basis for criminalisation, displacing competing theories such as legal moralism and leading to the proliferation of 'harm' arguments across the political spectrum. Harcourt suggests that this proliferation has 'effectively eviscerated the ability of the harm principle to limit the legal regulation and punishment of morality'102 resulting in it collapsing 'under the weight of its own success'. ${ }^{103}$

It is undeniably true that all ethical theories are subject to the dangers of appropriation and overextension in their application. Moreover, no ethical theory, however sophisticated in its refinement, provides definitive answers to how policy and law ought to be formulated. There are limits to pure moral reasoning in the formation of laws: at best, it can offer normative criteria that establish a reasonable range of options for courts and legislators to pursue, but social decision must play a critical supplementary role within that range. ${ }^{104}$ The fact that the harm principle has become overused in practice does not diminish its normative significance.

It is beyond the scope of this article to provide a deep justification for the harm principle as the basis for criminalisation. As stated in the introduction, the method by which this article's conclusion is arrived at is immanent critique, i.e. UK law's absence of any meaningful restrictions on the killing of animals is deficient according to its own standards. As Harcourt argues, the harm principle has become hegemonic as the basis for criminalisation in the context of modern, liberal, multicultural democracies. The harm principle is the most widely accepted guidance as to what conduct ought and ought not be criminalised. I will precede on the assumption that the harm principle is the best account

\footnotetext{
${ }^{101}$ See Bernard E. Harcourt, 'The Collapse of the Harm Principle' (1999) 90(3) Journal of Criminal Law and Philosophy 109. Whilst criminal law scholars generally accept that the harm principle plays an important role in determining the permissibility of criminalisation, they differ with regard to the precise nature of that role. Andrew von Hirsch describes it as a 'prima facie reason for criminalizing conduct'. Andrew von Hirsch, 'The Offence Principle in Criminal Law: Affront to Sensibility of Wrongdoing?' (2000) 11(1) Kings College Law Review 79, 79. Erik Luna interprets the harm principle as 'the sole justification' for criminalisation'. Erik Luna, 'The Overcriminalization Problem' (2005) 54(3) American University Law Review 703, 734. Chris Clarkson has described it as a minimal but not sufficient condition to criminalise conduct. Chris Clarkson, Introducing Criminal Law (London: Sweet and Maxwell 2006) 263. Alan Bogg and John Stanton-Ife identify the principle as a filter for the types of conduct that cannot be regarded as criminal. Alan Bogg and John Stanton-Ife, 'Protecting the Vulnerable: Legality, Harm and Theft' (2003) 23 Legal Studies 402, 409. Whilst I believe that a 'thin' account of the harm principle only provides a minimal, but not sufficient, condition for criminalising conduct, a 'thick' account, correctly formulated, supplies good reason for criminalisation. See discussion below.

102 Bernard E. Harcourt, 'The Collapse of the Harm Principle Redux: On Same-Sex Marriage, the Supreme Court's Opinion in United States v. Windsor, John Stuart Mill' s essay On Liberty (1859), and H.L.A. Hart's Modern Harm Principle' (2013) 103 ibid.

104 John Tasioulas, 'Towards a Philosophy of Human Rights' (2013) 65 Current Legal Problems 1, $26-27$.
} 
we have for thinking about when criminalisation is appropriate, and will argue that, based on the best account we have of the principle, there is good reason to introduce a general animal killing offence.

\section{(a) The Harm Principle: From Mill to Feinberg}

The locus classicus of the harm principle is found in John Stuart Mill's On Liberty: 'The only purpose for which power can be rightfully exercised over any member of a civilised community, against his will, is to prevent harm to others.' ${ }^{105}$ According to this liberal principle, harm to others is necessary to justify the imposition of a criminal sanction. Establishing mere immoral behavior or self-directed harm is standardly not regarded as enough to legitimate criminal sanction.

Are animals included as 'others' within Mill's principle? It certainly seems that Mill himself believed that they are. Mill was a staunch advocate of punishing animal cruelty, arguing that ' $[\mathrm{t}]$ he reasons for legal intervention in favour of children, apply not less strongly to the case of those unfortunate slaves and victims of the most brutal part of mankind, the lower animals.' ${ }^{106}$ Unlike many of his Victorian counterparts, Mill did not believe that the basis for punishing animal cruelty lay primarily in averting the moral corruption of those who engaged in it, but rather on account of the welfare of animals itself being of direct moral salience. ${ }^{107}$ He followed his philosophical mentor Bentham in believing that the act of inflicting suffering on a sentient creature - human or nonhuman - is intrinsically harmful, and therefore worthy of criminalisation in the absence of sufficient countervailing considerations. ${ }^{108}$

Mill's harm principle provides the starting point for establishing a liberal framework for the criminal law. It does however suffer from two major limitations. First, it only provides the necessary rather than the sufficient conditions for criminalisation and therefore does not provide much guidance as to which types of harmful conduct should be criminalised. Second, the conceptual centrepiece - harm - is, by itself, somewhat of a nebulous concept, open to varying interpretations.

In late $20^{\text {th }}$ century the American philosopher Joel Feinberg set about the task of clarifying and systematising the harm principle. In 1984, he published The Moral Limits of the Criminal Law: Harm to Others, which explored the contours of the harm principle

\footnotetext{
105 John Stuart Mill, On Liberty (OUP 1859) 22.

106 John Stuart Mill, Stephen Nathanson (ed), Principles of Political Economy: With Some of Their Applications to Social Philosophy (Indianapolis: Hackett Publishing Company) 291.

${ }^{107}$ John Stuart Mill, 'The Case of William Burn', The Morning Chronicle (17 November 1846). Cited in Andrew Linzey and Paul Barry Clarke (eds) Animal Rights: A Historical Anthology (Columbia University Press 1990) 84-87.

108 John Stuart Mill, Dissertations and Discussions: Political, Philosophical, and Historical Vol III (Henry Holt 1874) 165 (approvingly quoting Bentham on the moral salience of animal suffering).
} 
and developed fifteen 'mediating maxims' to assist in its application. ${ }^{109}$ The harm principle is reformulated in the following way:

'It is always a good reason in support of penal legislation that it would probably be effective in preventing (eliminating, reducing) harm to persons other than the actor (the one prohibited from acting) and there is probably no other means that is equally effective at no greater cost to other values.'110

Feinberg thus recalibrates the principle in such a way that it not only provides the necessary conditions for the imposition of criminal liability, but also provides a good reason for criminalisation. Feinberg places three important limitations on the harm principle: (1) criminalisation must be likely to be effective in preventing harm to others (the 'effectiveness' requirement); (2) there are no other means than criminalisation that would be as effective at no greater cost to other values (the 'proportionality' requirement) and; (3) the harm done must be wrongful (the 'wrongfulness' requirement). Whether the first two limitations are applicable when one is assessing any instance of criminalisation or potential criminalisation largely depends on empirical considerations and will not be considered in this article. The third limitation, the wrongfulness requirement, involves a more normative evaluation and will be briefly discussed. For Feinberg $A$ wrongfully harms $B$ when the following five criteria are met:

'1. $A$ acts...

$2 \ldots$ with the intention of producing the consequences for $B$ that follow, or similarly adverse ones, or with negligence or recklessness in respect to those consequences; 3. $A$ 's acting in that manner is morally indefensible, that is, neither excusable nor justifiable; and

4. A's action... (adversely affects)... B's interests, which is also

5. a violation of $B$ 's right.'111

An act is harmful where it adversely affects $B$ 's interests, and this harm is wrongful where it is done with: (a) the requisite culpable mind set ('mens rea'); (b) lacks either justification or excuse; and (c) violates the rights of $B$.

Some might question whether Feinberg's restatement of the harm principle extends to animals. ${ }^{112}$ There are at least two possible lines of objection. First, the passage cited above

\footnotetext{
109 Joel Feinberg, The Moral Limits of the Criminal Law Volume 1: Harm to Others (OUP 1984) 214-217, 243-245.

110 ibid, 26.

111 ibid, 105-106.

${ }^{112}$ Some have claimed that Feinberg's harm principle is formulated in a way that expressly precludes animals. These accounts are based on a misreading of Feinberg. In Volume IV of the Moral Limits, Feinberg states that 'In the primary sense of harm,
} 
refers to harm to persons (call this the personhood objection). Second, Feinberg asserts that for a harm to be wrongful it must involve a rights violation. Many jurists and philosophers argue that animals, most of them at least, do not and cannot possess rights (call this the rights objection). These two objections to extending the harm principle to animals will now be considered.

\section{(b) Are only persons protected by the harm principle?}

An initial response to the personhood objection is to note that the terms 'person' and 'human' are not synonymous and indeed many metaphysical accounts of personhood exclude some humans and include some nonhumans. ${ }^{113}$ Feinberg himself rejected a simple equation of personhood and humanhood. ${ }^{114}$ However, elsewhere Feinberg acknowledged that whilst he recognised that there are some definitions of personhood that could accommodate animals, he nevertheless thinks that there are good reasons to avoid referring to animals as persons. ${ }^{115}$ It is not entirely clear how much significance one should attach to Feinberg's use of person in his formation of the harm principle. In some formations he uses broader categories such as 'victim' or ' $B$ ', but I will now argue that if person is used in this context to exclude animals then it is inconsistent with Feinberg's overall approach.

Feinberg defines a person as a 'being who is a conceptually appropriate subject of both rights and duties'. ${ }^{116}$ As animals lack the capacity to bear duties, or so it is standardly believed, it follows that they are not persons. Yet, as Feinberg himself acknowledges, this definition of personhood also excludes human infants ${ }^{117}$ and it is clear that his account of the harm principle is intended to protect such individuals. As such, it would seem that Feinberg's harm principle is intended to cover a class of individuals broader than persons (on his own definition of the term). Perhaps one could argue that his harm principle is

\footnotetext{
only beings with interests can be harmed, and that account excludes mere things, artefacts and lower animals...'. However, 'lower animals' ought not to be understood as 'all animals other than humans' rather than 'animals that lack the capacity for sentience'. Feinberg's gives the 'wanton, capricious squashing of a beetle' as an example of a 'harmless wrong'. He explains: 'Human beings and some of the higher animals do have an interest in staying alive which is harmed by their premature deaths. If a beetle has any interests at all, as opposed to mere instinctual urges and propensities, then no doubt an interest in staying alive is one of them, but it is implausible, I think, to ascribe desires, goals, projects, or aspirations to a creature whose cognitive capacities (if any at all) are so primitive. So I doubt whether one harms such a being by painlessly killing it.' Feinberg explicitly notes that higher animals can be harmed and there is nothing in his account to suppose that it would not apply at least to mammals and birds. Joel Feinberg, The Moral Limits of the Criminal Law Vol IV: Harmless Wrongdoing (OUP 1988) 22-23, 24.

113 See e.g. Peter Singer, Practical Ethics (CUP, 2 $2^{\text {nd }}$ ed 1993) 87.

114 Joel Feinberg, 'Abortion' in Joel Feinberg, Freedom and Fulfilment: Essays (Princeton University Press 1992) 46-47.

115 Joel Feinberg, 'Human Duties and Animal Rights' in Joel Feinberg, Rights, Justice and the Bounds of Liberty (Princeton University Press 1980) 191-193.

116 ibid, 191.

117 Joel Feinberg, 'The Rights of Animals and Unborn Generations', in Joel Feinberg, Rights, Justice and the Bounds of Liberty ibid, 163.
} 
intended to cover not just present persons, but also future or potential persons. As (at least most) infants are future or potential persons, they are included within the principle. There are however at least three reasons to doubt the adequacy of this expanded account of personhood. To begin with, there is the logical problem of how one derives present moral status purely based upon one's potentiality. ${ }^{118}$ Feinberg himself rejected such claims and argued that 'merely potential possession of any set of qualifications for a moral status does not logically ensure actual possession of that status'. ${ }^{119}$ To illustrate this, he cites Stanley Benn's example that 'A potential president of the United States is not on that account Commander-in-Chief [of the U.S. Army and Navy]'. ${ }^{120}$

There are also normative reasons not to interpret the scope of the harm principle in this manner. The first of these is that such a rendering of the harm principle would be over-inclusive. For potential persons not only include human infants and babies but also early-term foetuses, embryos and zygotes. Whatever one's moral position on abortion is, it seems implausible to suppose that pre-sentient entities are suitable candidates for the harm principle. This is because the principle protects against setbacks to an individual's interests and in order for an individual to possess interests they must have, at the least, subjective desires and/or experiential welfare (what Feinberg calls 'welfare interests').121 Pre-sentient foetuses, embryos and zygotes lack any capacity for consciousness, let alone any of the attributes of personhood, and as such do not have any interests that can be adversely affected, at least in the sense that Feinberg understands the concept of an interest. They have the potential to develop into beings that possess such interests, but not the possession of such interests. ${ }^{122}$

One could rescue the potentiality account of personhood from the over-inclusiveness objection if one were to modify it to require both the possession of sentience and the potential to become a person. However, this revised position has the problematic feature of under-inclusion. For it suggests that both infants who have a terminal illness which will result in death before they achieve the attributes of personhood and humans who

\footnotetext{
${ }^{118}$ For an account of the moral and metaphysical significance of potentiality see Evelyn B. Pluhar, Beyond Prejudice: The Moral Significance of Human and Nonhuman Animals (Duke University Press 1995) 107-113.

${ }^{119}$ Feinberg, 'Abortion' (n 114) 48. See also, Feinberg, 'The Rights of Animals and Unborn Generations' (n 117) 183-184.

${ }^{120}$ Feinberg, 'Abortion' (n 114) 48-49.

${ }^{121}$ Feinberg, 'Harm to Others' (n 109) 37. Although for contrast see Don Marquis, 'Why Abortion if Immoral' (1989) 86 Journal of Philosophy 183 (arguing that pre-sentient human organisms can be harmed by abortion because they have 'a valuable future like ours' that we deprive them of).

122 The claim that only presently sentient beings have moral status requires further qualification to plausibly account for our considered judgements about the moral status of individuals who have temporarily lost sentience. On this see Sherry F Colb and Michael C. Dorf, Beating Hearts: Abortion and Animal Rights (Columbia University Press 2016) 106-111. Some argue that non-sentient entities have interests. For a defence of this position see Matthew H. Kramer, 'Do Animals and Dead People Have Legal Rights?' (2001) 14(1) Canadian Journal of Law and Jurisprudence 29, 33. For a critique of this position see Alasdair Cochrane, Animal Rights Without Liberation (Columbia University Press 2012) 36-38.
} 
have congenital severe cognitive impairments which mean that they both lack the attributes of personhood and will never develop them are not directly included within the harm principle. Yet it is clear that Feinberg would not have intended this outcome and indeed such a reading could not be endorsed by anybody with an elementary respect for basic human rights. As such, it seems impossible to use personhood in Feinberg's sense as the basis for protection under the harm principle without leading to unsavoury results in relation to humans who lack the attributes of personhood. ${ }^{123}$

The above supplies reason to doubt that personhood (defined in such a way as to necessarily exclude, at least most, animals) is a suitable candidate for the possible subjects of the harm principle. However, this does not deliver the conclusion that the harm principle extends to (at least some) animals: it might be the case that the harm principle merely includes human persons and human non-persons. I believe that there is reason to support the view that the harm principle extends to all sentient animals. This certainly seems to be Feinberg's own position: in a number of essays, he argued for the imposition of criminal liability for acts of animal cruelty. ${ }^{124}$ In his four volume work on the moral limits of the criminal law he makes it clear that ' $[t]$ he harm and offence principles, duly clarified and qualified, between them exhaust the class of good reasons for criminal prohibitions.' ${ }^{125}$ In other words, the only legitimate bases for criminalising conduct are that such conduct harms or causes serious offence to others. Feinberg makes it clear that the basis for prohibiting cruelty to animals is not because it is an affront to the sensibilities of other humans (i.e. the offence principle) but because it wrongs the animals themselves. ${ }^{126}$ Therefore, as neither the offence principle is engaged, nor can legal moralism or paternalism can be appealed to, it appears that the only remaining basis for such criminalisation is the harm principle. Indeed, in an earlier work, Feinberg himself states that the 'most inviting' account of why cruelty to animals ought to be criminalised is that the harm principle includes animals. ${ }^{127}$

\footnotetext{
123 There are two further options that would expand the definition of personhood to include all or most (born alive) humans. The first is the 'kind argument'. This argues that $\mathrm{X}$ is a person if and only if they either possess the attributes of personhood themselves or belong to a kind most of whose members possess the attributes of personhood. For a powerful critique of such 'kind' arguments see Nathan Nobis, 'Carl Cohen's "Kind" Arguments For Animal Rights and Against Human Rights' (2004) 21(1) Journal of Applied Philosophy 43. A more recent argument, advanced by Shelly Kegan, is that 'modal personhood', i.e. the status of once having the potential to be a person, confers an amplificatory moral status on an entity akin to 'honorary personhood'. See Shelly Kagan, 'What's Wrong with Speciesism?' (2016) 33(1) Journal of Applied Philosophy 1. See also responses from Jeff McMahan, Peter Singer and David Degrazia in the same volume. ${ }^{124}$ Joel Feinberg, 'Hard Cases for the Harm Principle' in Joel Feinberg, Social Philosophy (Upper Saddle River: PrenticeHall 1973) 41: Feinberg, 'The Rights of Animals and Unborn Generations' (n 117); Feinberg, 'Human Duties and Animal Rights' (n 115).

${ }^{125}$ Feinberg, 'Harm to Others' (n 109) 26.

${ }^{126}$ Feinberg, 'Human Duties and Animal Rights' (n 115) 188-189.

127 Joel Feinberg, 'Hard Cases for the Harm Principle' (n 124) 41.
} 
The principal reason to suppose that the harm principle extends to other animals is that the function of the harm principle is to protect individuals against the wrongful adverse interference with their interests. I will deal with the issue of wrongfulness in the next subsection, but for now I will simply note that animals who possess sentience have interests: at a minimum we can say that they, like humans, have pro tanto interests in experiencing pleasure and avoiding suffering. To exclude those interests from any direct protection, or give insufficient weight to them, simply by virtue of the fact that they do not share the same biological species membership as humans, seems as morally arbitrary as excluding or giving insufficient weight to the interests of a human simply by virtue of their gender, race or sexuality. ${ }^{128}$

Indeed, Feinberg himself has argued that membership of the species homo sapiens per se is not a necessary condition for possessing moral status because 'there is a possibility of there being moral persons from other planets who belong to other biological species'. ${ }^{129}$ However, personhood is also not a necessary criterion for inclusion within the scope of the harm principle, because, as argued above, that would be insufficiently inclusive of humans who are standardly assumed to be protected by the criminal law. Thus, neither humanhood nor personhood are necessary conditions for inclusion within the protective ambit of the harm principle. Instead, the necessary and sufficient condition for inclusion within the harm principle is the possession of interests. And the necessary and sufficient condition for the possession of interests is the possession of sentience. ${ }^{130}$ It follows that all individuals who are sentient, including sentient nonhuman animals, should be included within the framework of the harm principle.

\section{(c) Can animals possess rights?}

At this point, the critic opposed to extending the harm principle to animals might concede that whilst it is true that animals have interests that can be adversely affected, and hence harmed on Feinberg's account, they cannot be wrongfully harmed in the relevant sense because this involves not merely an adverse interference with interests but also a violation of rights. By rights, Feinberg means moral rights, i.e. claims backed by valid reasons and addressed to the conscience of the claimee or to public opinion. ${ }^{131}$ The critic might argue that animals do not, and cannot, possess moral rights and therefore are not suitable candidates for the harm principle. There are two arguments commonly deployed

\footnotetext{
${ }^{128}$ Peter Singer, Animal Liberation (Pimlico 1995) 1-23.

${ }^{129}$ Feinberg, 'Abortion' (n 114) 46.

${ }^{130}$ Cochrane, (n 122) 29.

${ }^{131}$ Feinberg, Harm to Others, (n 109) 110.
} 
by jurists and philosophers against the claim that animals possess rights. The first is the moral agent argument which asserts that the domain of rights-holders is restricted to those agents who are capable of acting morally and of being able to understand and comply with duties. Animals lack the cognitive sophistication to constitute moral agents (or so it is standardly assumed) and hence cannot possess rights. ${ }^{132}$ Alternatively, the will theory account of rights holds that to be a rights-holder one must exert some sort of normative control over a correlative duty-bearer, and this involves, for example, the capacity to enforce or waiver a duty. ${ }^{133}$ Again, animals are generally regarded as lacking the linguistic and conceptual apparatuses to exert these forms of normative control.

The moral agent argument for denying animals rights is structurally identical to the personhood argument discussed in the previous section and, mutatis mutandis, suffers from the same central defect: in its unrefined version it seems to constrict the category of rights-holders too narrowly by excluding certain beings standardly recognised as rightsbearers. For example, infants and adult legal incompetents such as the congenitally severely cognitively impaired, the brain-damaged and those in the late stages of Alzheimer's disease are widely recognised as bearers of both moral (and legal) rights, despite their potential lack of capacity to operate as moral agents or autonomous beings. As discussed above, attempts to refine the personhood requirement to make it more palatable are also not successful for various reasons. The will theory account fails on the same grounds: just as it is implausible to suppose that infants lack moral rights in virtue of their inability to exert normative control over a duty-bearer, so too is it implausible to deny that animals possess them on the same grounds. ${ }^{134}$

\footnotetext{
${ }^{132}$ Carl Cohen, 'The Case for the Use of Animals in Biomedical Research' (1986) The New England Journal of Medical Law 315; Tibor R. Machan, 'Do Animals Have Rights' (1991) 5(2) Public Affairs Quarterly 163; Peter Carruthers, The Animals Issue: Moral Theory in Practice (CUP, 2002). This position was accepted in the legal context in the New York case of Matter of Nonhuman Rights Project, Inc. v Lavery 2017 NY Slip Op 04574 (reaffirming a lower court ruling that a chimpanzee could not be a legal person with rights because they could not bear legal duties). This line of reasoning was subsequently criticised in the concurring judgement of Justice Fahey in the State of New York Court of Appeals. See In the Matter of Nonhuman Rights Project, Inc., on Behalf of Tommy 2018 Motion No.2018-268 at p.3-4. For a critique of the lower court ruling and the notion that being a legal person is a necessary condition for the possession of legal rights see Visa A.J Kurki, 'Why Things Can Hold Rights: Reconceptualizing the Legal Person' in Visa A.J Kurki and Tomasz Pietrzykowski (eds) Legal Personhood: Animals, Artificial Intelligence and the Unborn (Springer 2017) 69.

${ }^{133}$ H. L. A Hart, 'Legal Rights' in H. L. A Hart, Essays on Bentham: Studies in Jurisprudence and Political Theory (Clarendon, 1982) 162; N.E Simmonds, 'Rights at the Cutting Edge' in Matthew Kramer, Nigel Simmonds and Hillel Steiner, A Debate Over Rights (OUP, 2000) 113; Hillel Steiner, 'Working Rights' in Kamer, Simmonds and Steiner, 233; Siegfried Van Duffel, 'In Defence of the Will Theory of Rights' (2012) 18 Res Publica 321-331.

${ }^{134}$ In response to concerns that the will theory prescribes a counter-intuitively narrow domain of rights-holders, some defenders of the theory have relaxed the criteria for the degree of normative control required over a duty-bearer. For example, revised accounts of the will theory have found it sufficient that an agent can enforce or waiver duties on the behalf of the individual to whom the duty is owed. However, as agents can likewise enforce or waiver duties owed to animals such reformations of the will theory also accommodate the idea that animals can possess rights. See Visa A.J. Kurki, 'Rights, Harming and Wronging: A Restatement of the Interest Theory’ (2018) 38(3) Oxford Journal of Legal Studies 430, 448-449.
} 
As such, neither the moral agent argument nor the will theory provide a fully comprehensive account of how rights operate in our moral communities, or indeed in our legal systems, and should therefore be rejected. ${ }^{135}$

Feinberg's account of rights is more inclusive. He defines rights as claims which can be made either by individuals or representatives acting on their behalf. ${ }^{136}$ As such, it allows that small children, individuals who are seriously mentally disabled and animals may possess rights. According to Feinberg 'the sorts of beings who can have rights are precisely those who have (or can have) interests.' ${ }^{137}$ Given that sentient animals are capable of possessing interests, so too are they capable of possessing rights.

If animals are conceptually capable of possessing rights, the further question to be asked is in what circumstances we deem an animal possesses any particular right. To determine this Feinberg proposes the following:

if we hold not only that we ought to treat animals humanely but also that we should do so for the animals' own sake, that such treatment is something we owe animals as their due, something that can be claimed for them, something the withholding of which would be an injustice and a wrong, and not merely a harm, then it follows that we do ascribe rights to animals. ${ }^{138}$

So an animal possesses a right against human moral agents when: (1) we have a duty towards them; (2) we owe them that duty for their sake, and; (3) it would be a wrongful injustice not to perform the duty. This account is similar to Joseph Raz's famous version of the interest theory of rights, which holds that a being is capable of having rights if and only if [...] his well-being is of ultimate value'. ${ }^{139}$ Do animals possess 'ultimate value'? As I argued in part 3, the view underpinning our contemporary animal welfare law is that animals possess an independent worth by virtue of their sentience and their wellbeing is of ultimate value rather than merely derivative or instrumental value. This view seems to be the most plausible. To illustrate this, Feinberg gives the following example:

John Doe: Suppose that John Doe is an intelligent, sensitive person with one very severe neurotic trait - he loves to see living things suffer pain. Fortunately, he

\footnotetext{
135 This argument, recurrent in the literature in animal ethics, is known as 'the argument from marginal cases' or 'the argument from species overlap'. There is not space in this article to do sufficient justice to the intricacies of the debate around this argument but, suffice to say that I do not believe there are any compelling responses to it by those who wish to extend rights to all humans and to no non-human animals. For a detailed response to attempts to rebut the marginal cases challenge see Pluhar (n 118) 67-179.

${ }^{136}$ Feinberg 'The Rights of Animals and Unborn Generations' (n 117) 162-163.

137 ibid, 167.

138 ibid, 166

139 Joseph Raz, The Morality of Freedom (Clarendon Press 1988) 166.
} 
never has occasion to torture human beings (he would genuinely regret that) ... Doe buys a five hundred acre ranch, and moves into a house in the remote, unpopulated centre of his own property. There, in the perfect privacy of his own home, he spends every evening maiming, torturing, and beating to death his own animals. ${ }^{140}$

Feinberg has modelled this admittedly bizarre thought experiment in such a way that there are no adverse side-effects for humans of John Doe's abuse of animals - and yet it is clear that his conduct is still monstrously immoral. One could claim that the reason it is so is because it reveals John's morally corrupt character but it seems implausible to suppose that this is the main reason why his act his wrongful. The better explanation is that John's infliction of misery and pain on the animals amounts to a breach of a duty he owes the animals not to inflict gratuitous suffering on them. This is a direct duty that John, and all other moral agents, owe to animals, and failing to abide by that duty is a rights violation that the law ought to offer protection against. This direct duty, I suggested in part 3 , is already recognised by the UK's existing animal welfare law.

\section{(d) The harm of death}

In the previous section I argued that animals are appropriately thought of as protected by the harm principle. ${ }^{141}$ In part 3, I argued that the primary reason for such laws today is because we as a society think that the suffering of animals is inherently bad and should be minimised. The basis for this is surely obvious: as Bentham put it, sentient individuals are governed by two sovereign masters: pain and pleasure. ${ }^{142}$ We think that it is intrinsically bad, all else equal, for individuals, including animals, to experience pain or suffering. But the implicit corollary of this is that pleasure is intrinsically good: the intrinsic harm of suffering and intrinsic good of pleasure are two sides of the same coin. It further follows from this that depriving an individual of pleasure is also bad for that individual. ${ }^{143}$ As animals experience pleasure as well as pain, depriving them of pleasure they might otherwise have had also harms them. This should give us reason to think that death in some circumstances harms animals (and humans for that matter) by depriving

\footnotetext{
${ }^{140}$ Feinberg, 'Hard Cases for the Harm Principle' (n 124) 41.

${ }^{141}$ This is reflected in the law. For example, the second crossheading in the Animal Welfare Act (2006) groups all the proceeding offences under the banner of 'prevention of harm'.

${ }^{142}$ Bentham, Principles of Morals and Legislation (n 44) 1. Note that one can accept Bentham's hedonistic account of harm whilst rejecting the aggregative aspect of his normative ethics.

${ }^{143}$ Which is not necessarily to say that there isn't an asymmetry between these harms.
} 
them of the future good experiences they might otherwise have had. Call this the deprivation account of the harm of death:

Deprivation Account: death is harmful for an individual if it makes that individual's lifetime well-being lower than it otherwise would have been. ${ }^{144}$

Consider now the following vignette, based on Feinberg's John Doe example discussed in the previous section:

Jane Doe: Suppose that Jane Doe is an intelligent, sensitive person with one very severe neurotic trait: she loves to see sentient creatures be killed. Fortunately, she never has occasion to kill human beings (she would genuinely regret that)... Doe buys a five hundred acre estate, and moves into a house in the remote, unpopulated centre of her own property. There, in the perfect privacy of her own grounds, she spends every morning shooting puppies she has purchased at a pet store. Let us further suppose that Jane is a skilled marksperson and can kill the puppies instantly without causing them any suffering.

This scenario is identical to Feinberg's John Doe case but for the fact that Jane does not torture the animals, or indeed inflict any suffering on them at all. Has she harmed them? According to the deprivation account of the harm of death it is plausible to suppose that she has: if she had not purchased them and terminated their lives they could have been purchased by other people who could have given them good lives containing plenty of pleasurable experiences such as comfy bedding, walks in the park, belly rubs, nice food, play, companionship and so on. By purchasing and killing these puppies, Jane deprives them of all the pleasurable future experiences they could otherwise have had, and in circumstances where the remainder of the puppy's life would have had a net surplus of pleasure over pain we can say that Jane harms them by reducing their lifetime well-being to a lower level than it would otherwise have been.

\footnotetext{
${ }^{144}$ The deprivation account of the harm of death is not accepted by all bioethicists. A competing school of thought - the desirebased account - argues that death is harmful for an individual if and only if it frustrates a relevant desire or desires that the individual had at some point before the death occurred. See for example, Bernard Williams, 'The Makropulos Case: Reflections on the Tedium of Immortality' in John Martin Fischer, The Metaphysics of Death (Stanford University Press, $1^{\text {st }}$ ed,1973) 7392. There is not space in this article to consider the desire-based account but I believe it is far less compelling than the deprivation account in explaining the harm of death. For some critiques of this account see Jeff Mcmahan 'Preferences, Death and the Ethics of Killing' in Christoph Fehige et al (eds) Preferences (Walter de Gruyter, 1998) 471; Ben Bradley and Kris McDaniel, 'Death and Desire' in James Stacey Taylor (ed), The Metaphysics and Ethics of Death: New Essays (OUP 2013) 118. Others jettison 'subjectivist' accounts of wellbeing in favour of measuring wellbeing against an 'objective list' of goods. For a critique of this position see David Degrazia, 'Sentient Nonpersons and the Disvalue of Death' (2016) 7(30) Bioethics 511-519.
} 
Animals are not merely pain avoiders but also pleasure seekers: we harm them when we deprive them of the goods of life by killing them. Where we lack sufficient reason to kill animals it ought to be criminal offence to cut short their lives.

\section{CONCLUSION}

This article has argued that there is a principled case for introducing an animal killing offence in UK law. Two independent but complementary arguments have been advanced to support this view. The first was that animal welfare has independent value and is worthy of legal protection. To the extent that death deprives an animal of a life worth living, it is an interference with their welfare interests, and in the absence of compelling reasons for doing so, it ought to be criminalised. The second line of argument was that death harms animals for the aforementioned reason and that this provides grounds for criminalising such killing as animals are appropriately thought of as protected by the harm principle.

This, of course, is only the start of the debate about future legal reform. My conclusions thus far in the article have been intentionally vague: they have only suggested that there is good reason to criminalise some instances involving the killing of animals, but have not spelt out precisely what those instances are. The scope of any future criminalisation will not merely rest upon metaphysical claims about the harm of death nor normative claims about its moral salience, but also upon a host of social and policy considerations that are beyond the purview of this article.

That being said, the continued silence of UK law on the question of killing animals is no longer tenable. There is now an unprecedented debate about the moral status of animals in modern society, particularly in light of studies revealing that animals possess an array of emotions and capacities, many of which were once thought of as uniquely human. ${ }^{145}$ Nevertheless, apart from the small (though growing) percentage of the population who are embracing veganism, most consumers are happy to purchase food and clothes that require the killing of animals, and practices such as pest control and using animals in medical research are largely unchallenged by the public. Whilst these practices are still routine in society, the scope of any feasible animal killing offence will be circumvented by them. In current conditions I believe that two new animal killing offences are feasible:

1. A prohibition on killing autonomous non-human animals: these are animals for which there is robust scientific evidence demonstrating that they have self-awareness, a

\footnotetext{
${ }^{145}$ See generally Frans de Waal, Are We Smart Enough to Know How Smart Animals Are? (Granta 2016).
} 
strong sense of the past and future and can act intentionally in order to fulfil their desires. Such species include at least the nonhuman great apes (chimpanzees, bonobos, orangutans and gorillas), cetaceans (whales, dolphins and porpoises) and elephants. ${ }^{146}$ Guaranteeing the 'right to life' for such animals would be fairly straightforward in the UK context. Their particular moral status is already partially recognised in law. Scientific experiments on the great apes has been formally banned since 2012 (and de facto proscribed long before), ${ }^{147}$ the UK signed the International Whaling Commission's moratorium on commercial whaling in $1982^{148}$ and is opposed to the hunting of cetaceans. ${ }^{149}$ A number of UK zoos contain great apes and elephants: there is a strong case that such creatures should neither be kept in such places nor be killed but rather transferred to sanctuaries to live out the rest of their lives. ${ }^{150}$ Prohibiting the killing of these animals (with defences for genuine euthanasia and self-defence) would raise very few practical concerns (it covers a narrow class of animals) and would be in keeping with the recognition of the special moral status of such animals already implicit in much UK and EU law.

2. An 'unnecessary killing' offence for all other sentient animals - for all other sentient animals there should be a prohibition against unnecessarily killing them. This would roughly mirror the German and Austrian approaches which proscribe the killing of animals without a 'good' or 'sound' reason. In practice, like in Germany and Austria, such a law would permit the killing of animals for many of the usual reasons that humans kill them: for food, clothing, scientific research and so on, but could prohibit killing outside of such circumstances. Killing animals for convenience, fun, sport or target practice might be examples of instances that might fall foul of such an offence. However, as with unnecessary suffering, the concept of unnecessary killing is an inherently flexible one that will evolve with a society's norms and mores. What we regard as a 'necessary' killing today may well be regarded as unnecessary in 10 years' time.

This is of course only a very rough proposal. This author is less concerned with the precise formulation of a future animal killing law than with the recognition within legal circles that the absence of any such an offence is a significant gap in UK animal protection

\footnotetext{
${ }^{146}$ See generally Steven Wise, Drawing the Line: Science and the Case for Animal Rights (Perseus 2002).

147 Animals (Scientific Procedures) Act 1986 Amendment Regulations 2012 (S.I. 2012/3039)

${ }^{148}$ Katie Sykes, 'The Appeal to Science and the Formation of Global Animal Law' (2016) 27(2) European Journal of International Law 497, 501.

${ }^{149}$ Foreign \& Commonwealth Office, 'UK's position on the hunting of whales, dolphins and porpoises' (6 February 2015)

$<$ https://www.gov.uk/government/publications/uks-position-on-the-hunting-of-whales-dolphins-and-porpoises> accessed 14 August 2018.

${ }^{150}$ This is the argument made by the US based 'Nonhuman Rights Project'. See

$<$ https://www.nonhumanrights.org/litigation/> It was accepted by an Argentine Court in the case of a chimpanzee in a zoo. See Presented by A.F.A.D.A About the Chimpanzee 'Cecilia' - Non Human Individual (2016) File No P-72.254/15.
} 
legislation. It is hoped that the arguments presented in this article will be a starting point for a more rigorous discussion about what the law's position ought to be in relation to the killing of animals, particularly in light of the recent explicit recognition from UK legislators of the moral salience of animal sentience. 